\title{
ACTIVITY OF THE LIVER MITOCHONDRIAL ASPARTATE AMINOTRANSFERASE AND MALATE DEHYDROGENASE IN RATS WITH TOXIC HEPATITIS UNDER CONDITIONS OF ALIMENTARY PROTEIN DEFICIENCY
}

\author{
O. M. Voloshchuk, G. P. Kopylchuk \\ o.voloschuk@chnu.edu.ua
}

Chernivtsi national university named by Yurii Fedkovych, Institute of Biology, Chemistry and Bioresources, 2 Kotsyubinskogo str., Chernivtsi 58012, Ukraine

Nutritional demands in proteins depend on the life stage and health status of organisms. Both humans and experimental animals under stress conditions and especially drug processing become to be more sensitive to the protein deficit in the food. In this study, we examined some acetaminophen-induced metabolic effects potentiated by alimentary protein deprivation (APD) in rat liver. In particular, activities of the liver mitochondrial aspartate aminotransferase and malate dehydrogenase in rat liver were studied in conditions of balanced and imbalanced by protein diets of isocaloric content. It has been found that acute acetaminophen-induced hepatitis in comparison to control does not change the activity of mitochondrial malate dehydrogenase causing simultaneous 4-fold reduction in activity of mitochondrial aspartate aminotransferase and 2.5-fold reduction of mitochondrial oxaloacetate content. Interestingly, alimentary protein deprivation enhances the effects of acetaminophen on the described parameters. Finally, in order to confirm these associations between amount of the protein in the rat diet and physiological measures in their liver with toxic injury, principal component analysis (PCA) was performed. Two principal components characterize changes in physiological measures in our study. Principal component 1 explains about $86 \%$ of the variation among whole dataset mainly related to control group and group subjected to acetaminophen treatment with simultaneous APD. It reveals the tight association of scores for AST activity and oxaloacetate level with control group, which might indicate the high efficiency in the oxaloacetate conversion by AST lacked in both groups with hepatitis. Similarly, principal component 1 explaining the variance in MDH activity shows its linkage to the control group, indicating the importance of MDH for the health status of control animals. On the other side, principal component 2 reveals close association between lactate and pyruvate levels as well as cytosolic $N A D^{+} / \mathrm{NADH}$ ratio with acetaminophen-treated group of animals subjected to APD, confirming that toxic liver injury associated with low protein consumption leads to increased lactate-pyruvate turnover in cytosol affecting. This potentially might be associated with energy-generating dysfunction in liver under toxic hepatitis on the background of dietary protein deficiency.

Keywords: ACETAMINOPHEN, LIVER, INJURY, ASPARTATE AMINOTRANSFERASE, MALATE DEHYDROGENASE

\section{АКТИВНІСТЬ МІТОХОНДРІАЛЬНИХ ЕНЗИМІВ АСПАРТАТАМІНОТРАНСФЕРАЗИ ТА МАЛАТДЕГІДРОГЕНАЗИ У ПЕЧІНЦІ ЩУРІВ 3 ТОКСИЧНИМ ГЕПАТИТОМ ЗА УМОВ АЛІМЕНТАРНОЇ НЕСТАЧІ ПРОТЕЇНУ}

\author{
О. М. Волошук, Г. П. Копильчук \\ o.voloschuk@chnu.edu.ua
}

\begin{abstract}
Чернівецький національний університет імені Юрія Федьковича, Інститут біології, хімії та біоресурсів, вул. Коцюбинського, 2, м. Чернівці, 58000, Україна
\end{abstract}

Потреба у протеїнах залежсть від стадї̈ життя і стану здоров'я організмів. Як люди, так і експериментальні тварини в умовах стресу та особливо використання ліків стають чутливішими до дефіциту протеїну в їжі. Метою роботи було дослідження деяких метаболічних ефектів у печіниі за умов нестачі харчового протеїну у тварин з ацетамінофен-індукованим гепатитом. Зокрема, визначали активність мітохондріальних ензимів аспартатамінотрансферази та малатдегідрогенази у печіниі шурів з токсичним гепатитом за умов різної забезпеченості раціону харчовим протеїном. Встановлено, щчо за умов гострого ацетамінофен-індукованого гепатиту не спостерігаються зміни активності мітохондріальної малат- 
дегідрогенази при одночасному 4-кратному зниженні активності мітохондріальної аспартатамінотрансферази та 2,5-кратному зниженні вмісту мітохондріального оксалоащетату. Цікаво, щуо аліментарна депривація протеїну посилює вплив аџетамінофену на описані параметри. Для того, щуоб підтвердити залељність міз кількістю протеїну в раціоні щурів і метаболічними змінами у печінці за умов токсичного ушкодження, було застосовано метод головних компонент (РСА). Дві головні компоненти характеризують зміни у намому дослідженні. Головна компонента 1 пояснює близько $86 \%$ відхилень між повним набором даних, здебільиого пов'язаних з контрольною групою і групою протеїн-дефіцитних тварин з ацетамінофен-індукованим ушкодженням. Виявлено щуільну асоціацію балів для активності АСТ та рівня оксалоацетату порівняно з контрольною групою в обох групах з гепатитом. Аналогічно, головна компонента 1, щзо пояснює дисперсію в активності малатдегідрогенази, вказує на важливість малатдегідрогенази для стану здоров'я тварин. 3 іниого боку, головна компонента 2 виявляе тісний зв 'язок між рівнями лактату і пірувату, а також співвідношенням циттозольного $\mathrm{NAD}^{+} / \mathrm{NADH}$ у групі протеїн-дефіцитних тварин, які отримували ацетамінофен. Встановлений факт підтверджує, щуо токсичне ушкодження печінки на тлі низького споживанням протеїну супроводжується інтенсифікацією перетворення лактат-піруват у циттозолі. Це потениійно може бути пов 'язано з дисфункцією енергозабезпечення у печінці при токсичному гепатиті на тлі аліментарної нестачі протеїну.

Ключові слова: АЦЕТАМІНОФЕН, ПЕЧІНКА, УШКОДЖЕННЯ, АСПАРТАТАМІНОТРАНСФЕРАЗА, МАЛАТДЕГІДРОГЕНАЗА

\title{
АКТИВНОСТЬ МИТОХОНДРИАЛЬНЫХ ЭНЗИМОВ АСПАРТАТАМИНОТРАНСФЕРАЗЫ И МАЛАТДЕГИДРОГЕНАЗЫ В ПЕЧЕНИ КРЫС С ТОКСИЧЕСКИМ ГЕПАТИТОМ В УСЛОВИЯХ АЛИМЕНТАРНОЙ БЕЛКОВОЙ НЕДОСТАТОЧНОСТИ
}

\author{
О. Н. Волощук, Г. П. Копьльчук \\ o.voloschuk@chnu.edu.ua
}

\begin{abstract}
Черновицкий национальный университет имени Ю. Федьковича, Институт биологии, химии и биоресурсов, ул. Коцюбинского, 2, г. Черновцы, 58000, Украина
\end{abstract}

Потребность в белках зависит от стадии жсизни и состояния здоровья организмов. Как люди, так и экспериментальные жсиотные в условиях стресса и особенно при употреблении лекарств становятся более чувствительными к дефициту белка в пище. Целью работы было исследование некоторых метаболических эффектов дефицита пищевого белка в печени у животных с ацетаминофен-индуцированнылм гепатитом. Изучали активность митохондриальных ферментов аспартатаминотрансферазы и малатдегидрогеназы в печени крыс с токсическим гепатитом в условиях различной обеспеченности рациона пищзевым белком. Установлено, что в условиях острого ацетаминофен-индуцированного гепатита активность митохондриальной малатдегидрогеназы не изменяется при одновременном 4-кратном снижении активности митохондриальной аспартатаминотрансферазы и 2,5-кратном снижении содержания митохондриального оксалоацетата. Интересно, что депривация пищевого белка усиливает действие ацетаминофена на описанные параметры. Для подтверждения зависимости между количеством протеина в пищевом рационе крыс и метаболическими изменениями в печени в условиях токсического повреждения, проведен анализ главных компонент (РСА). Две главные компоненты характеризируют изменения в нашем исследовании. Главная компонента 1 объясняет около $86 \%$ отклонений между набором данньх, связанных с контрольной группой и группой протеин-дефицитных животных с ацетаминофен-индуцированнылм повреждением. Установлена ассоциаџия баллов активности АСТ и уровня оксалоацетата по сравнению с контрольной группой у обеих групп с гепатитом. Аналогично, главная компонента 1, указывающая на дисперсию в активности малатдегидрогеназы, свидетельствует о важности малатдегидрогеназы для состояния здоровья. С другой стороны, главная компонента 2 обнаружсвает тесную связь между уровнями лактата и пирувата, а такюе соотношением ичитозольного $N A D^{+} / N A D H$ в группе протеин-дефицитных животных, получавиих ацетаминофен. Установленный факт подтверждает, что токсическое повреждение печени на фоне низкого употребления протеина сопровождается интенсификацией преврашения лактат-пируват в циитозоле. Указанные изменения потенциально могут быть связаны с дисфункцией энергообеспечения в печени при токсическом гепатите на фоне алиментарного дефицита белка.

КлючевЫе слова: АЦЕТАМИНОФЕН, ПЕЧЕНЬ, ПОВРЕЖДЕНИЕ, АСПАРТАТАМИНОТРАНСФЕРАЗА, МАЛАТДЕГИДРОГЕНАЗА 
Proteins are essential macronutrients used in various cellular processes. A lack of protein in the diet (alimentary protein deficiency, APD) can cause a set of metabolic abnormalities associated with repressed growth and increased mortality [17]. At the organismal level, an important role in the coordination of protein metabolism belongs to the liver. Liver is also known to be the main detoxification organ during xenobiotic and drug administration [6]. As the processes of xenobiotic metabolism require multiple biochemical transformations, and some intermediates mediate toxic responses [5], one may suggest that liver might be potentially susceptible to drug injury upon the lack of protein in the diet. Such a case might be a problem in developing countries, where low dietary protein associated with high levels of pollutants and xenobiotics in the environment as well as administration of untested or old generation drugs in the medicine is a common issue. For example, acetaminophen (known also as paracetamol), one of the most widely used analgesics in the therapeutic practice in developing countries, possesses a high risk to cause liver injury [8]. However, the effects of acetaminophen administration associated with low protein intake on metabolic processes liver cells remains unknown.

In this study, we have examined some acetaminophen-induced metabolic effects potentiated by alimentary protein deprivation (APD) in rat liver. In particular, the effects of acetaminophen on cytoplasmic $\mathrm{NAD}^{+} / \mathrm{NADH}$ ratio and functioning of malate-aspartate shuttle mitochondrial enzymes in rat liver were studied in conditions of balanced and imbalanced by protein diets of isocaloric content.

\section{Materials and methods}

Experimental Design and Procedures. In the study, 8-10 week old white nonlinear rats weighing 90-100 g were used. Animals were kept in individual plastic cages with sand bedding; they were fed twice per day having ad libitum access to water. The experiment was conducted in accordance with the rules set by the "European convention for the protection of vertebrate animals used for experimental and other scientific purposes" (Strasbourg, 1986).

For the study, animals were divided into three groups: I - control group of rats maintained on the balanced diet (C, control group); II — rats with acute acetaminophen-induced hepatitis, maintained on the balanced diet ( $\mathrm{H}$, group with hepatitis); III — rats with acute acetaminophen-induced hepatitis, maintained under the conditions of alimentary deprivation in protein (APD+H, alimentary deprivation in protein + hepatitis). Each experimental group had from 6 to 10 animals. Over 4 weeks, animals of the $\mathrm{C}$ and $\mathrm{H}$ experimental groups were fed balanced diet containing $14 \%$ protein (in the form of casein), $10 \%$ fat and $76 \%$ carbohydrates [4]. Animals of the APD+H group were fed for 4 weeks isoenergetic food containing $4.7 \%$ protein, $10 \%$ fat and $85.3 \%$ carbohydrates. After 4 weeks, toxic hepatitis was caused in the $\mathrm{H}$ and APD+Hexperimental groups by per os administration of acetaminophen. For this, acetaminophen was added to the food at a dose $1 \mathrm{~g} / \mathrm{kg}$ in a $2 \%$ starch suspension for 2 days [14]. Animals were euthanized on the $31^{\text {st }}$ day of the experiment. The rats were sacriced by decapitation 48 hours after the paracetamol application, their livers were quickly removed.

Liver tissue was homogenized in 9 volumes of cold buffer at $4{ }^{\circ} \mathrm{C}$. The homogenates were then centrifuged at $4{ }^{\circ} \mathrm{C}(1000 \mathrm{~g} / \mathrm{min}, 10 \mathrm{~min})$.

The mitochondrial fraction of the liver homogenate was isolated by differential centrifugation (Heraeus Biofuge, Germany) at $0-3{ }^{\circ} \mathrm{C}$ in the following buffer medium: $250 \mathrm{mM}$ sucrose, $1 \mathrm{mM}$ EDTA, $10 \mathrm{mM}$ Tris- $\mathrm{HCl}$; $\mathrm{pH} 7.4$ at $0-3{ }^{\circ} \mathrm{C}$. The cytosol fraction of homogenates was isolated after the separation of microsomal fraction [11].

Enzyme assays. The activities of mitochondrial aspartate aminotransferase (AST, EC 2.6.1.1) and malate dehydrogenase (MDH, EC 1.1.1.37) were measured spectrophotometrically at $340 \mathrm{~nm}$ as described earlier $[2,19]$.

Lactate and pyruvate assays. The content of lactate was evaluated using the enzymatic method according to [3] in the presence of lactate dehydrogenase - EC 1.1.1.27 (the final activity in the incubation mix $-2 \mathrm{IU} / \mathrm{ml}), 0.05 \mathrm{M}$ NAD in glycine-hydrazine buffer $(0.4 \mathrm{M}$ hydrazine sulphate, $1 \mathrm{M}$ glycine, $0.2 \%$ EDTA-Na, $\mathrm{pH}$ 9.5) The formation of reduced NADH, which quantity is equivalent to the amount of oxidized lactate, was registered photometrically at the wavelength $340 \mathrm{~nm}$.

The content of pyruvate in the cytosolic fraction was determined spectrophotometrically in test with iron (III) nitrate [7]. 
Oxaloacetate concentration measurement. Concentration of oxaloacetate was determined by colorimetric method based on the interaction of oxaloacetate 2.4-dinitrophenylhidrazine and formation of oxaloacetate hydrazone with maximum absorption at $546 \mathrm{~nm}$ [9].

The cytoplasmic $N A D^{+} / N A D H$ ratio assay. The cytoplasmic ratio $\mathrm{NAD}^{+} / \mathrm{NADH}$ was calculated taking into account the equilibrium constant of the lactate dehydrogenase reaction as was proposed previously $[13,16]$ :

$\frac{\mathrm{NAD}^{+}}{\mathrm{NADH}+\mathrm{H}^{+}}=\frac{1}{1,11 \times 10^{-4}} \times \frac{[\text { Pyruvate }]}{[\text { Lactate }]}$

Statistical analysis. Statistical analysis was performed by T-test using Statistica 6.0 software (StatSoft, USA). All of the data was tested for normal distribution using Levene's test and one-sample Kolmogorov-Smirnov test, respectively. Characteristics of the study group were expressed as Mean \pm Standart Deviation for normal distribution. The probability, $\mathrm{P} \leq 0.05$ was accepted to have critical level of significance. Principal component analysis was done using JMP Pro 11 software (SAS Institute, USA).

\section{Results and discussion}

The hepatocytes' system of energy biotransformation determines the ability of an organism to restore its wellness after a toxic injury of many xenobiotics including acetaminophen $[1$, 12]. Simultaneously, the efficiency of hepatocytes to rebuild the metabolism upon xenobiotic stress depends on nutritional conditions. In this study, we aimed to disclose the biochemical adaptation of hepatocytes' malate-aspartate shuttle mitochondrial enzymes in rats subjected to low protein diet upon acetaminophen-induced toxicity. The choice of malalate-aspartate shuttle as an indicator of hepatocyte functional state is related to its role in NAD oxidoreduction. In particular, the malate-aspartate shuttle system is the central metabolic pathway to transfer glycolytic NADH from the cytoplasm to mitochondria for further NADH oxidation $[15,18]$.

First, we evaluated the activities of mitochondrial NAD-dependent malate dehydrogenase
$(\mathrm{MDH})$ and aspartate aminotransferase (AST). We have found that acetaminophen does not affect activity of mitochondrial NAD-dependent $\mathrm{MDH}$ in the liver of rats fed a protein balanced diet (fig. 1A). However, conversion of malate to oxaloacetate by this enzyme to be lower in the liver of animals subjected to APD. Thus, activity of malate dehydrogenase was 52 and $34 \%$ lower in the APD $+\mathrm{H}$ group. Reduction in activity of mitochondrial aspartate aminotransferase (fig. 1B)
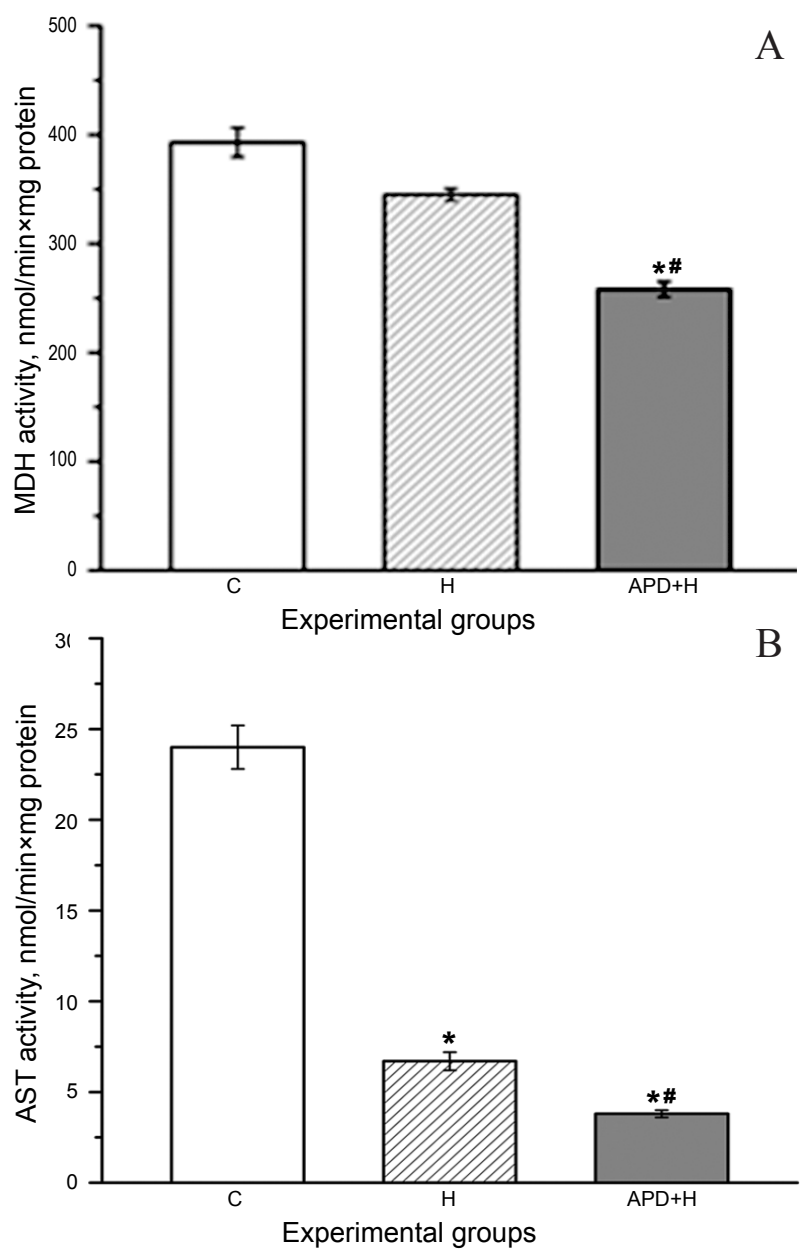

Fig. 1. $\mathrm{NAD}^{+}$-malate dehydrogenase (MDH, A) and aspartate aminotransferase (AST, B) activities of liver mitochondria under toxic hepatitis with and without alimentary protein deprivation. The data are presented as means \pm standard error means (S.E.M.), $\mathrm{n}=8-10$

Note: $\mathrm{C}$ bar shows the value of parameter in the liver of control group of rats maintained on the balanced diet; $\mathrm{H}$ bar shows the value of parameter in the liver of rats with acute acetaminophen-induced hepatitis, maintained on the balanced diet; APD+H bar shows the value of parameter in the liver of rats with acute acetaminophen-induced hepatitis, maintained under alimentary protein deprivation (APD). * - significantly different from the control (C) group. ${ }^{\#}$ - significantly different from the group with acetaminophen-induced hepatitis. $\mathrm{P} \leq 0.05$ represents statistical significance. 
was found upon acetaminophen treatment when compared to the enzyme activity in liver of rats in the control group. However, APD enhanced the reduction in activity of mitochondrial aspartate aminotransferase in rat liver. Thus, the activity of the enzyme was 6-fold lower in the liver of ADP animals with acetaminophen-induced hepatitis than in the control group (fig. 1B).

Neither lactate nor pyruvate concentration were affected by acetaminophen in the cytosolic fraction in liver of rats (Fig. 2.A, 2B). However, the concentration of lactate and pyruvate in the cytosolic fraction of liver of rats subjected to APD with simultaneous acetaminophen treatment was $60 \%$ and 3,3-fold higher respectively than in controls and animals with toxic hepatitis. In the opposite, the amount of oxaloacetate in liver mitochondria of rats decreased upon acetaminophen treatment. Moreover, APD enhanced the effect of acetaminophen (fig. 2C).

Since oxaloacetate in mitochondria is a substrate for both aspartate aminotransferase and citrate synthase, reduction in the activity of mitochondrial aspartate aminotransferase may indicate enhanced use of oxaloacetate in the tricarboxylic acid cycle (TCA) in the liver of acetaminophen-treated animals. It seems that APD enhances the use of oxaloacetate in liver mitochondria upon acetaminophen-induced hepatitis, which might lead to the increased oxidation of NADH formed in TCA by mitochondrial respiratory chain. As the state of energy supply to the cells primarily depends on the efficiency of the mitochondrial respiratory chain $[10,14]$, the reduction in activity of malate-aspartate shuttle mitochondrial enzymes in rat liver may indicate different rate of NADH oxidation in the cytosol and mitochondria.

Finally, in order to confirm these associations between amount of the protein in the rat diet and physiological measures in their liver with and without toxic injury, principal component analysis (PCA) was performed. Scree plot for the used types of diets and score plot for the measured metabolic parameters were combined in biplot for graphical representation of PCA (fig. 3). Two principal components characterize changes in physiological measures in our study.
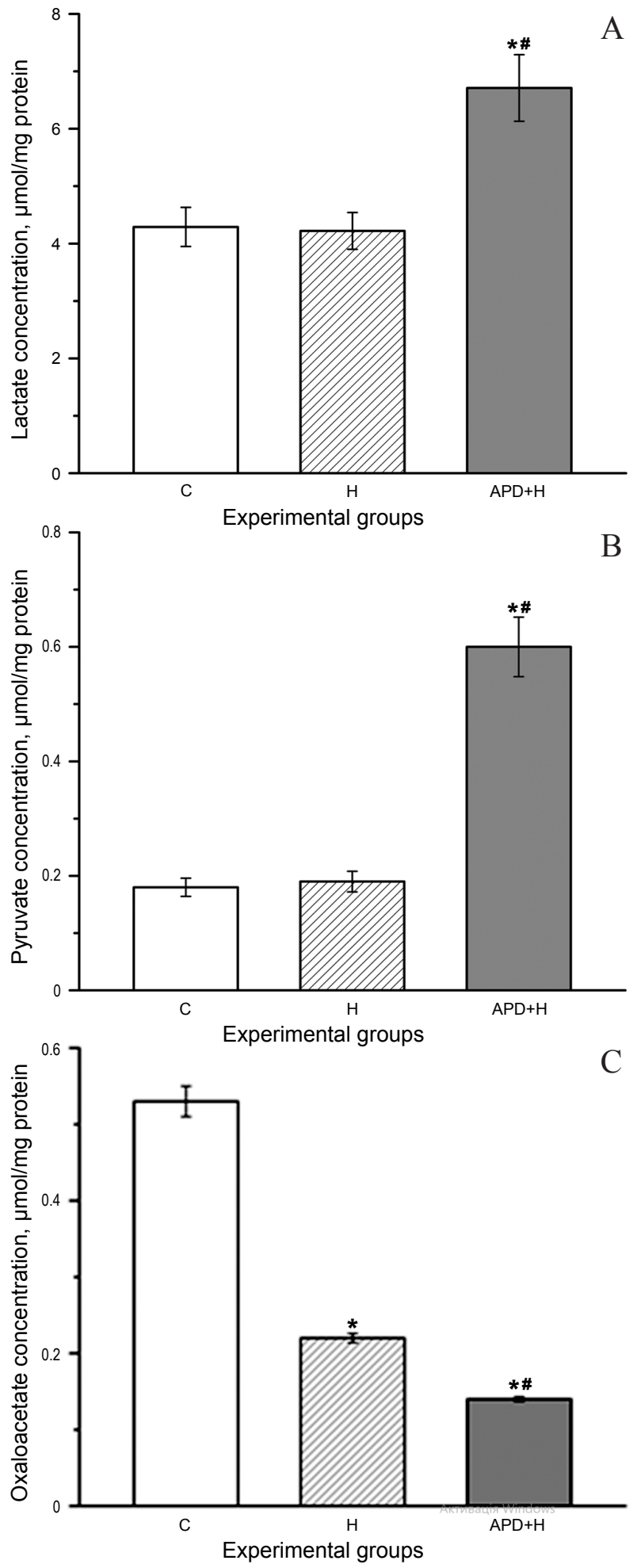

Fig. 2. Lactate (A), pyruvate (B) in the cytosolic fraction and oxaloacetate $(\mathrm{C})$ concentrations in mitochondria in liver of rats under toxic hepatitis with and without alimentary protein deprivation. The data are presented as means \pm standard error means (S.E.M.), $n=6-10$

Principal component 1 explains about $86 \%$ of the variation among whole dataset mainly related to control group and group subjected to acetaminophen treatment with simultaneous APD. 


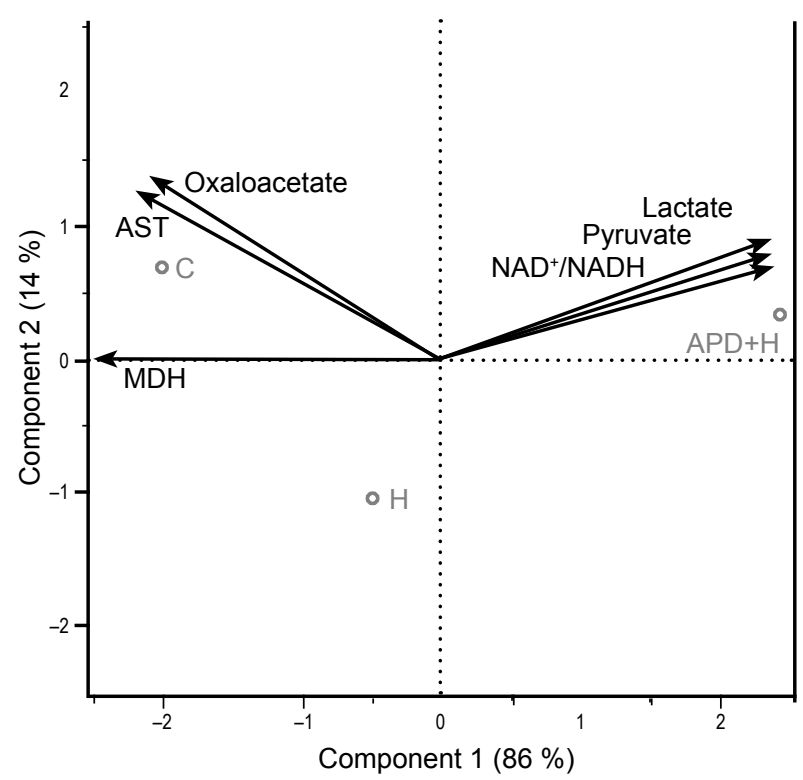

Fig. 3. Principal component analysis some of the indices which characterize malate-aspartate shuttle functioning in liver mitochondria under toxic hepatitis with and without alimentary protein deprivation

It reveals the tight association of scores for AST activity and oxaloacetate level with control group, which might indicate the high efficiency in the oxaloacetate conversion by AST lacked in both groups with hepatitis. Similarly, principal component 1 explaining the variance in MDH activity shows its linkage to the control group, indicating the importance of $\mathrm{MDH}$ for the health status of control animals. On the other side, principal component 2 reveals close association between lactate and pyruvate levels as well as cytosolic $\mathrm{NAD}^{+} / \mathrm{NADH}$ ratio with acetaminophen-treated group of animals subjected to APD, confirming that toxic liver injury associated with low protein consumption leads to increased lactate-pyruvate turnover in cytosol affecting, thus, $\mathrm{NAD}^{+} / \mathrm{NADH}$ flux.

\section{Conclusion}

The data suggests that alimentary protein deficiency might aggravate the metabolic imbalance in the liver after its toxic injury. Particularly, the association of toxic hepatitis with APD in rats leads to the reduction in the activities of malate-aspartate shuttle mitochondrial enzymes and glycolytic NADH inflow to the mitochondria. This potentially might be associated with energygenerating dysfunction in liver under toxic hepatitis on the background of dietary protein deficiency.

Perspectives of the future investigations. The obtained results open prospectives for the further study of the mechanisms of energy supply disturbance in the liver under conditions of its toxic damage with the different content of protein. It plan to investigate the activity of the main enzymes of glycolysis and the Krebs cycle in the liver under the experimental conditions for the purpose of justification of approaches to correction of energy disturbance.

Acknowledgements. The authors want to acknowledge Troy Faithfull and Bohdana Rovenko (University of Helsinki, Finland) for the English grammar correction and advice concerning manuscript structure and principal component analysis.

1. Carvalho N. R., da Rosa E. F., da Silva M. H., Tassi C. C., Dalla Corte C. L., Carbajo-Pescador S., Mauriz J. L., González-Gallego J., Soares F. A. New therapeutic approach: diphenyl diselenide reduces mitochondrial dysfunction in acetaminopheninduced acute liver failure. PLoS One, 2013, vol. 8, issue 12, e81961. DOI: 10.1371/journal. pone.0081961.

2. Cetica P., Pintos L., Dalvit G., Beconi M. Involvement of enzymes of amino acid metabolism and tricarboxylic acid cycle in bovine oocyte maturation in vitro. Reproduction, 2003, vol. 126, issue 6, pp. 753-763. DOI: 10.1530/reprod/126.6.753.

3. Khyzhnyak S. V., Sorokina L. V., Stepanova L. I., Kaplia A. A. Functional and dynamic state of inner mitochondrial membrane of sarcoma 37 in mice under administration of sodium dichloroacetate. The Ukrainian Biochemical Journal, 2014, vol. 86, issue 6, pp. 106-118. DOI: 10.15407/ubj86.06.106.

4. Kopylchuk G. P., Voloshchuk O. M. Peculiarities of the free radical processes in rat liver mitochondria under toxic hepatitis on the background of alimentary protein deficiency. The Ukrainian Biochemical Journal, 2016, vol. 88, issue 2, pp. 66-72. DOI: 10.15407/ubj88.02.066.

5. Lerapetritou M. G., Georgopoulos P. G., Roth C. M., Androulakis L. P. Tissue-level modeling of xenobiotic metabolism in liver: An emerging tool for enabling clinical translational research. Clinical and Translational Science, 2009, vol. 2, issue 3, pp. 228-237. DOI: $10.1111 /$ j.1752-8062.2009.00092.x.

6. Licata A. Adverse drug reactions and organ damage: The liver. European Journal of Internal Medicine, 2016, vol. 28, pp. 9-16. DOI: 10.1016/j. ejim.2015.12.017.

7. Mehrotra R. N., Hasan T. Detection and spectrophotometric determination of pyruvic acid. Analytical 
Letters, 1986, vol. 19, issue 17-18, pp. 1713-1724. DOI: $10.1080 / 00032718608066497$.

8. Mund M. E., Quarcoo D., Gyo C., Brüggmann D., Groneberg D. A. Paracetamol as a toxic substance for children: aspects of legislation in selected countries. Journal of Occupational Medicine and Toxicology, 2015, vol. 10, p. 43. DOI: 10.1186/s12995-015-0084-3.

9. Olayinka E. T., Ore A., Ola O. S., Adeyemo O. A. Protective effect of quercetin on melphalan-induced oxidative stress and impaired renal and hepatic functions in rat. Chemotherapy Research and Practice, 2014, vol. 2014, article ID 936526, 8 p. DOI: $10.1155 / 2014 / 936526$.

10. Sangar V., Eddy J. A., Simeonidis E., Price N. D. Mechanistic modeling of aberrant energy metabolism in human disease. Frontiers in Physiology, 2012, vol. 3, article ID 404, 10 p. DOI: 10.3389 / fphys.2012.00404.

11. Schenkman J. B., Cinti D. L. Preparation of microsomes with calcium. Methods in Enzymology, 1978, vol. 52, pp. 83-89. DOI: 10.1016/S0076-6879(78) 52008-9.

12.Somanawat K., Thong-Ngam D., Klaikeaw N. Curcumin attenuated paracetamol overdose induced hepatitis. World Journal of Gastroenterology, 2013, vol. 19, issue 12, pp. 1962-1967. DOI: 10.3748/wjg.v19.i12.1962.

13. Sun F., Dai C., Xie J., Hu X. Biochemical issues in estimation of cytosolic free NAD/NADH ratio. PLoS One, 2012, vol. 7, issue 5, e34525. DOI: 10.1371/journal.pone.0034525.
14. Voloshchuk O. M., Kopylchuk G. P. Activity of liver mitochondrial $\mathrm{NAD}^{+}$-dependent dehydrogenases of the Krebs cycle in rats with acetaminophen-induced hepatitis developed under conditions of alimentary protein deficiency. Biomeditsinskaya Khimiya, 2016, vol. 62, issue 2, pp. 169-172. DOI: 10.18097/PBMC20166202169. (in Russian)

15.Wang C., Chen H., Zhang J., Hong Y., Ding X., Ying W. Malate-aspartate shuttle mediates the intracellular ATP levels, antioxidation capacity and survival of differentiated PC12 cells. International Journal of Physiology, Pathophysiology and Pharmacology, 2014, vol. 6, issue 2, pp. 109-114.

16. Williamson D. H., Lund P., Krebs H. A. The redox state of free nicotinamide-adenine dinucleotide in the cytoplasm and mitochondria of rat liver. Biochemical Journal, 1967, vol. 103, issue 2, pp. 514-527. DOI: 10.1042/bj1030514.

17. Wu G. Dietary protein intake and human health. Food \& Function, 2016, vol. 7, issue 3, pp. 12511265. DOI: $10.1039 / \mathrm{C} 5 \mathrm{FO} 01530 \mathrm{H}$.

18. Ying W. NAD $/$ NADH and $\mathrm{NADP}^{+} / \mathrm{NADPH}$ in cellular functions and cell death: regulation and biological consequences. Antioxidants \& Redox Signaling, 2008, vol. 10, issue 2, pp. 179-206. DOI: 10.1089/ars.2007.1672.

19.Zhou Y.-H., Shi D., Yuan B., Sun Q.-J, Jiao B.-H., Sun J. J., Miao M.-Y. Mitochondrial ultrastructure $\&$ release of proteins during liver regeneration. The Indian Journal of Medical Research, 2008, vol. 128, issue 2, pp. 157-164. 